Cahiers $d u$ MONDE RUSSE

\section{Cahiers du monde russe}

Russie - Empire russe - Union soviétique et États indépendants

$56 / 1 \mid 2015$

Fictions d'avenir : sciences et temps des socialismes est-européens

\title{
The future as an intellectual technology in the Soviet Union
}

From Centralised Planning to Reflexive Management

Le futur en tant que technologie intellectuelle en Union soviétique : de la planification centralisée au management réflexif

\section{Egle Rindzevičiūtè}

\section{(2) OpenEdition}

1 Journals

\section{Electronic version}

URL: http://journals.openedition.org/monderusse/8169

DOI: 10.4000/monderusse.8169

ISSN: $1777-5388$

\section{Publisher}

Éditions de l'EHESS

\section{Printed version}

Date of publication: 1 January 2015

Number of pages: 111-134

ISBN: 978-2-7132-2475-1

ISSN: $1252-6576$

\section{Electronic reference}

Egle Rindzevičiūtè, "The future as an intellectual technology in the Soviet Union », Cahiers du monde russe [Online], 56/1 | 2015, Online since 13 July 2019, connection on 11 October 2020. URL : http:// journals.openedition.org/monderusse/8169; DOI : https://doi.org/10.4000/monderusse.8169

This text was automatically generated on 11 October 2020

(c) École des hautes études en sciences sociales 


\title{
The future as an intellectual technology in the Soviet Union
}

\author{
From Centralised Planning to Reflexive Management ${ }^{1}$ \\ Le futur en tant que technologie intellectuelle en Union soviétique : de la \\ planification centralisée au management réflexif
}

\author{
Egle Rindzevičiūtè
}

1 The Soviet future, understood as the subject of utopian narratives, visual representations and plans, has been studied by cultural historians, sociologists and historians of science and technology, who, albeit focusing on different empirical material, shared a focus on the end products of Soviet futuring, such as visual images and stories, art and industrial projects. ${ }^{2}$ In contrast, this article shifts the focus from representations of the Soviet future to the much less known area of the mechanism of its production : the theories and methods of Soviet future studies. Given the abundance of work on Soviet and Western planning associated with the welfare state, the lack of knowledge on the role of future studies in these processes is quite astonishing. Yet I suggest that there is a good reason to scrutinise the history and legacy of Soviet future studies, for this was an area where some decidedly different notions of the future emerged, paving the way for the post-Soviet transformation. ${ }^{3}$ As a rule, such niche zones for the production of alternative futures were situated close to the centre of power, in the strategic areas of scientific expertise and industrial development. The history of Soviet future studies is therefore that of a transformation from within the system.

2 Discussing one of the most prominent examples of Soviet future studies, the case of the Russian philosopher and management guru Georgii Petrovich Shchedrovitskii (1929-1994), this article contributes new empirical material to social studies of the Soviet future, but also contributes to debates about informality as a central source of power in the Soviet regime, which left a significant legacy for post-Soviet development. I argue that the development of a new understanding of teleological or goal-oriented governance as a means of producing the future led to a significant transformation of 
the authoritarian Soviet regime, a process which had an ambivalent outcome. Although these new tools promised better control of the future, they eventually undermined the power monopoly of the Communist Party by creating new spaces of action and new sources of authority, such as the scientific methodology of management. This opened up a space for new actors and new methods, which smuggled in different versions of the Soviet future, underscoring uncertainty, plurality and less than optimistic visions. ${ }^{4}$

However, as the case of Shchedrovitskii shows, this dispersion of power over the future did not automatically lead to the shaping of institutions dedicated to the principles of openness and democracy, but rather reinforced and perpetuated informal relations. These informal relations performed a vital role under the Soviet regime by making the Soviet economy work; but, as Alena Ledeneva shows, informality turned out to be a "modernisation trap" in the post-Soviet context. Although the ambiguous role of informality in the Soviet society and economy has been studied extensively by Alena Ledeneva and Carole Sigman, we lack knowledge about the impact of informality in the development of post-Soviet policy sciences. ${ }^{5}$ If in the Soviet economic sphere informality was demonised as an informal economy, which at best compensated for the shortage economy, informal connections in the political sphere were interpreted as the cradle of civic society. During the post-Soviet period informal practices in both economy and politics became suspect as roots of corruption. However, social studies of informality, as well as management theory, suggest that formal rules and informal practices constitute a complex assemblage rather than conflict with one another. This is a significant issue because the Soviet future was set not only in the official planning guidelines produced by the Party, but it was also informally negotiated in dispersed academic and management milieus, particularly among the policy sciences, such as global modelling and forecasting. ${ }^{6}$

4 The case of Shchedrovitskii helps unlock this hidden history of an informally produced Soviet technology for shaping the future that emerged as an alternative to central planning ; first, through the conceptual approach of reflexivity in the 1960s, then as a widespread practice of activity-games in the late 1970s. This approach originated in the Moscow methodological circle (first called the Moscow logical circle, 1952-1954), which evolved from a student discussion group into a network revolving first around Aleksandr Zinov'ev and, from 1958, around Georgii Shchdedrovitskii. The members of the circle discussed Marxism, formal logic and social psychology, but also the nascent systems approach and information theory. Retrospectively Moscow methodologists described themselves as belonging to the systems approach. ${ }^{7}$

Although Shchedrovitskii was careful to record and otherwise document his activities, he remained invisible to scholars interested in institutional histories of Soviet governance. There is next to nothing published on him in Anglophone academia. One reason for this is that Shchedrovitskii was an intellectual entrepreneur who operated under the umbrella of many different institutes. His activities did not fit into the existing conceptual framework of analysis according to which research institutes fed data and methods to Gosplan, which churned out economic and social development plans and centrally administered them. ${ }^{8}$ Furthermore, in part because of this lack of stable institutional affiliation with planning bodies, Shchedrovitskii appears only in studies of philosophy or Soviet civil society. ${ }^{9}$ But Shchedrovitskii's legacy is not simply an intellectual curiosity: his case can be used as a key to understand both the Soviet and post-Soviet development of Russian governance. 
6 As a co-founder of the Moscow methodological circle, later known as the Moscow methodological school of management, Shchedrovitskii is well known in the circles of Russian management practitioners and policy makers as a mysterious, charismatic personality, described by one of his students as Voland, the dark character from Bulgakov's Master and Margarita. ${ }^{10}$ Shchedrovitskii was one of the first genuine management consultants and gurus in the Soviet Union: in the 1980s he conducted almost 100 training sessions, many of which hosted 150-200 practitioners and he left many followers, including his son, Petr Shchedrovitskii, who continues training Russian CEOs and who has himself occupied significant positions of authority, for instance, as director-general for strategy at the Russian nuclear authority Rosatom. The website of the Moscow-based Foundation of Shchedrovitskii lists 40 organisations and individual members of the methodological circle from Russia, Latvia and Ukraine. ${ }^{11}$ Whereas some of these members are the old-timers of the circle, such as the philosophers oleg Genisaretskii and Boris Sazonov, others include private consultancies providing expertise to corporations and governmental bodies, such as Moscow Methodological Corporation. Furthermore, shchedrovitskii's work is quoted in thousands of research papers and dissertations published mainly by Russian researchers in the fields of management, media studies, political science, philosophy and pedagogics. ${ }^{12}$

Moreover, the Shchedrovitskii legacy is not limited to an arcane society of management philosophers, but is endorsed by Vladimir Putin's government. For instance, several high ranking officials recently acknowledged drawing their inspiration and methods from Shchedrovitskii's work. These include Viktor Khristenko, previously the Minister of industry, trade and energy and, from 2011, the chairman of the board of the Eurasian Economic Commission, and Andrei Reus, a former director-general of Oboronprom, a Russian-Belarusian corporation specialising in the defence industry. ${ }^{13}$ Both Khristenko and Reus paid homage to Shchedrovitskii by publishing a sizeable collection on Shchedrovitskii's and their own writing, not only in Russian, but also in English with Bloomsbury. In 2015 this UK publication was shortlisted for the Chartered Management Institute's Management Book of the Year. In this way, Shchedrovitskii's thought had travelled quite a journey, from semi-underground discussion clubs of the 1950s to the boardrooms of Rosatom and the pages of an officially endorsed publication with a major London-based press. The question is : what made Shchedrovitskii's method of the control of the future relevant and resilient in the context of radical political and economic change?

One way to answer this question, I suggest, is to re-interpret the legacy of Shchedrovitskii in Soviet management and policy sciences, analysing his efforts as a particular attempt to harness informal practices to enhance the control of the future, practices which complemented the planning based on formal, scientific knowledge, typically pursued by high modernist states. By formal knowledge I mean the sciences produced within defined institutional environments, institutes and laboratories, documented in publications and fed to into the governmental process through reports and statistics; in short, the end products of future expertise. It is on this formal scientific knowledge that the existing studies of Soviet governance focus, attributing to the Soviet regime the characteristics of a high modernist state. ${ }^{14}$ Now, high modernist states, the argument goes, have a particularly formal take on time : time is a dimension produced by specific knowledge instruments, not only clocks, but also statistical time series, history and, more recently, an array of future studies methods. ${ }^{15}$ High modernist 
states seek to capture, understand and control the apparent chaos of life, giving birth to a number of new institutions and professions that mediate knowledge production, planning and governance. In the second half of the twentieth century a new class of so called technocrats engaged in Big Science emerged, seeking to enable precisely this kind of control over both short and long term. ${ }^{16}$ Yet the aim of Shchedrovitskii's methodology was exactly the opposite of the objectives of Big Science: instead of making things visible it made them invisible, seeking to de-stabilise and de-formalise managerial relations.$^{17}$ As a result, Shchedrovitskii developed a very particular thought collective for the production of the future, capable of surviving the overhaul of the Soviet state apparatus.

9 Thus I show how Shchedrovitskii's methodology, in particular his notion of "forward reflexiveness" (in Russian, vpered napravlennaia refleksiia and prospektivnaia refleksiia) challenged the input-output model of predictive expertise, according to which the information revealed by scientific forecasting was supplied to the Soviet planning organs to assist decision-makers. ${ }^{18}$ I detail the ways in which Shchedrovitskii developed his own model of the reflexive co-production of the future, as revealed in his theoretical writings and documentation of his workshops and lectures. A brief note on my sources is necessary. I mainly draw on the published primary materials, i.e. books, articles and memoirs published by Shchedrovitskii and his colleagues, which reveal the conceptual importance of informality for the future-oriented governance. They also contain some examples of informal interaction. However, Shchedrovitskii's workshops, through which he disseminated his ideas among practitioners, are never described in detail, for these workshops were confidential in their character. Nevertheless, the available sources, such as secondary comments and some transcripts of workshop discussions, are more than adequate to gain insight and appreciate the distinctive role that Shchedrovitskii's ideas played in the changing Soviet governance of the future. In what follows, I briefly outline the origins of teleological planning as a future-oriented governance in the West and the Soviet Union and then discuss the ways in which teleological planning was conceptualised and practiced in Shchedrovitskii's work.

\section{Who Sets the Goals ? Modifying Marxist Teleology through Cybernetics}

10 According to Andersson, the twentieth-century notion of the prediction of the future as a category of control has little to do with the centuries-long tradition of thinking about possible worlds or utopian societies, but refers instead to a particular understanding of the future as a product of special methods, such as scientific forecasting, foresight, and many other forms of future studies. ${ }^{19}$ These methods, which originated from a very particular development in military technology, were a part and parcel of a postwar governmentality, by which I refer, in line with Michel Foucault, to an assemblage of intellectual and material technologies of governance. ${ }^{20}$ The concept of governmentality is highly suitable to describe the assemblage of theories, networks and institutions that were generated by Shchedrovitskii not least because Shchedrovitskii's core belief was that knowledge could be used as a performative instrument of governance. The notion of intellectual technology, for Shchedrovitskii and his followers, was therefore not merely an analytical concept, but an instrument of governance that they sought to 
develop. In this section I thus contextualise this ambition in the history of postwar technologies of governance. ${ }^{21}$

During the Second World War the efforts to construct automatic anti-aircraft systems required quick, automatic prediction of the behaviour of an incoming enemy plane. The construction of such a tool made clear that it was not so much past causes, but future goals which determined behaviour in complex, man-machine systems. This phenomenon was theorised by the US scientists Norbert Wiener, a mathematician, Arturo Rosenblueth, a physiologist, and Julian Bigelow, a computer engineer, introducing the notion of teleological behaviour in $1943 .{ }^{22}$ The notion of teleological or goal-oriented - behaviour was created to explain, simulate and improve organisms and machines, for instance, a neural disorder such as Parkinson's disease, a digitally powered prosthetic arm, or a guided missile.

For us it is important to note that the idea of teleological behaviour drew on a particular notion of the future as an anticipated and predictable state. Thus, teleological behaviour was defined as a process that seeks a particular goal and continuously evaluates the present state with regards to an anticipated, final state. The goal is reached when the current state overlaps with the anticipated state. Goal-seeking behaviour, therefore, relies on communication with the external environment, flowing through feedback loops. In turn, goal-seeking behaviour operates on the basis of difference : the specific content of the representation of the anticipated future state is important but not sufficient to generate action. Instead it is the perceived difference between this representation of an anticipated state and the actual state that activates teleological behaviour.

The idea of teleological behaviour gained influence beyond engineering and medical applications in a wide range of fields leading to a rethinking of the character of order and control in politics, society and culture. In extreme technocratic instances the teleological governance of the future manifested in policy process through statistical calculations, used to achieve clearly defined goals. The teleological governance of the future entailed gathering predictive information about the future state of the governed systems, for instance, the economy, society or natural resources, and making decisions on the basis of this information. It is quite clear that understood this simply, teleological behaviour could be reconciled with state planning. It is in this sense that Soviet state planners declared that cybernetics was the foremost tool for helping the Party to reach the anticipated final state, communism. ${ }^{23}$ However, teleological behaviour cannot be limited to the processing of information: indeed, teleological behaviour is about goal-setting. Once the behaviour of individual managers, collectives or companies is framed as teleological, goal-seeking behaviour, their subservience to the Party becomes less self-evident. In complex systems, such as firms, states and societies, goal setting is highly problematic: in part, because goal-setting requires processing a large amount of information and, in part, because being socially negotiated, the goals tend to change over the course of action. For this reason, as I show in the next section, teleological behaviour turned out to be no mere instrument for implementing the communist utopia, but a source of contradictions and transformations.

That the development of predictive knowledge-based management did not bypass the Soviet Union says a lot about the elasticity of the notion of the communist future. It was not sufficient for Khrushchev to declare the coming of communism in twenty 
years : the Soviet planners needed to know the future states of natural resources both in the Soviet Union and in the world, the rate of the use of these resources, the growth of the Soviet and world population, and the emergence of new technology. In order to know all these futures, specific expertise was necessary. The development of such expertise, in turn, posited a need for institutional reform, enabling experts to access information and feed their studies into policy and management process. That this plurality of futures would be accommodated by Soviet planners from the beginning of the mid-1960s revealed their pragmatic intention to keep the Soviet economy going. This future-pragmatism, as I show in the case of Shchedrovitskii, was conducive to significant innovations.

15 Many studies have shown that the most influential scientific methodologies of anticipatory knowledge originated in the United States and the United Kingdom during the postwar period: these methods were first developed in military research institutes, such as the RAND Corporation in the 1940s, and spilled over into the emergent disciplines of management and economic planning in the 1950s-60s. ${ }^{24}$ The Soviets keenly borrowed these approaches, including Operations Research, game theory, technology assessment and the Delphi method, intending to use them to construct their own, socialist future. ${ }^{25}$ When in 1966 Kosygin's and Brezhnev's government claimed to be based on scientific knowledge of the future, they referred to highly formalised forms of knowledge, such as trend calculations, scenarios and expert surveys, which were to be used for "optimal" planning purposes. By adopting these scientific tools the Soviets thus opened up to the Western rationalisation of governance. $^{26}$

Scientific forecasting demanded data about the past and present to extrapolate alternative future scenarios. Elsewhere I have argued that the introduction of scientific forecasting to Soviet planning had an unexpected effect on existing administrative practices. For instance, economic forecasters based at Gosplan required transparency, understood as the free circulation of statistical data. ${ }^{27}$ This was not allowed: Soviet bureaucratic compartmentalisation and pervasive secrecy prevented the circulation of data across different branches. As a result, even branch forecasts were technically flawed, because they could not take into consideration the developments in connected branches. My argument is that it was another unintended effect of scientific forecasting which turned out to be more significant: scientific forecasters produced negative images of the Soviet future economy, natural resources and environment, feeding them through secret reports to the government. Scientific forecasting, in this way, was used to criticise both Soviet bureaucratic secrecy and contemporary policies. Instead of empowering the Soviet government, scientific forecasting eventually eroded the regime from within by pointing out the inadequacy of decision-making, based on informal bargaining among Gosplan officials and industry managers. ${ }^{28}$

But forecasting, an example of a highly formalised scientific expertise, was only one component in the complex milieu of Soviet governance, where informal, personal relations played an extremely important role, both in political and economic decision making. ${ }^{29}$ Despite being widespread, informal practices in governance were not legitimate in the Soviet Union: any divergence from the top-down organisation of democratic centralism and Party control was suspect and subject to the investigations of the security organs (KGB)..$^{30}$ Informal practices were something of a public secret : everyone knew about it, in particular the personalist approach to decision making, but 
this aspect was a source of anxiety that clashed with the ideal of formal steering. In the following sections I show that Shchedrovitskii's genius was precisely lending a formal, scientific methodology to provide legitimacy for informal planning of the future in Soviet firms and administrations.

\section{The First Soviet Management Guru}

18 Georgii Petrovich Shchedrovitskii's father was an aviation engineer, coming from a politically active family of Russian Jews, and his mother was a microbiologist. ${ }^{31}$ Georgii's family was close to strategic Soviet industries : having returned to Moscow after the war Georgii's father became the director of Orgaviaprom, the Research Institute for the Organisation of the Aviation Industry. In his memoir Georgii Shchedrovitskii recalls interacting daily with members of both party and military-industrial complex elites as a child. ${ }^{32}$ In this way yhe future semi-underground thinker and management guru grew up in a privileged social environment of committed communists, well integrated in the nomenclature networks of power. At school Georgii excelled in mathematics and enrolled to study physics at the prestigious Moscow State University (MGU) in 1946. However, Shchedrovitskii soon became attracted to broader questions and, to the disappointment of both his parents and physics teachers, transferred to the philosophy department in 1949, the year of harsh ideological attacks against "cosmopolitanism". Put off by the rigid observance of Marxist-Leninist dogmas and "continuous fear" among the faculty, he sought shelter in the department of logic, which was relatively immune to ideological dogmas. ${ }^{33}$ Shchedrovitskii graduated in 1953 and, from February 1954, launched a seminar on logic and philosophy at MGU, around which a group entitled the Moscow logical circle emerged. ${ }^{34}$ In 1956 Shchedrovitskii joined the Communist Party. During his subsequent career Shchedrovitskii belonged to several institutes: he was affiliated with the Academy of Pedagogical Sciences, then the All-Union Institute of Technical Aesthetics (VNIITE) in 1965-1969, and the Institute for the International Labour Movement (IMRD). Although Shchedrovitskii travelled abroad only once, to Bulgaria in 1991, his affiliation with these and other institutes facilitated his access to Western scholarship. ${ }^{35}$ Both VNIITE and IMRD were rare islands where social thought and the humanities could be developed in a less ideologically restricted environment. These spaces of relative liberty were restricted after the Prague Spring in $1968 .^{36}$

Soviet scientific forecasters were trained predominantly in mathematics, physics or engineering; the leading scholars gathered in the Scientific Research Institute of Economics at Gosplan, the Institute of Automation and Control, the Central Institute of Mathematical Economics (TsEMI) and, from 1976, the Institute of Systems Research (VNIISI). ${ }^{37}$ In contrast, Shchedrovitskii came to policy sciences from the field of philosophy and logic. These were not entirely different worlds : in the late 1950s and the 1960s the circles of humanities and mathematical scholars intertwined, in particular under the transdisciplinary umbrella of cybernetics. Indeed, the fascination with cybernetics and the emerging systems approach led to intense contacts across disciplines and institutes. Informal gatherings were not unusual, for instance several informal groups discussed ideas aiming to reform Marxism-Leninism, most famously in the circles around Evald Il'enkov. ${ }^{38}$ The so-called Moscow methodological circle also originated as an informal gathering of logic students in a pub on Gor'kii street, linking 
future prominent Russian thinkers such as the mathematician Aleksander Zinov'ev, author of a satire of Soviet academia The Yawning Heights, who fell out with the group in 1958 ; the sociologist Boris Grushin and Georgian philosopher Merab Mamardashvili.

The group attracted the attention of the KGB and the young scholars were questioned and reprimanded, but not prevented from meeting. After all, their intellectual interest concerned the highly strategic fields of cybernetics and the systems approach that lent legitimacy to the circle's intellectual experiments in philosophy. For instance, in 1962, together with later prominent systems theorists Vadim Sadovskii and Erik Iudin, Shchedrovitskii organised a seminar on systems analysis methods in science and technology under the Scientific Council for Cybernetics of the Academy of Sciences; the work of this seminar continued until 1976. In this seminar young scholars discussed Western approaches to general systems theory, an approach that was highly innovative in the 1960s and strongly promoted as part of the on-going efforts for the computerisation and automation of governance in the Soviet Union. ${ }^{39}$ Other systems thinkers, such as Igor Blauberg, formed a close circle of Shchedrovitskii's friends. Later in the 1960s Shchedrovitskii would co-author one of the first works on the systems approach in the Soviet Union. ${ }^{40}$ In all, the Moscow methodological circle sought to combine the emerging systems approach with Marxist political theory and epistemology : they revisited Marx's Capital searching for a definition of systematic and performative knowledge.

21 It is quite possible that being less interested in engineering systems and computer technology, Shchedrovitskii was more perceptive to social processes in organisations than the proponents of forecasting. He was deeply interested in Lev Vygotsky's idea of reflexivity in learning, with which he engaged in his candidate of science dissertation (kandidatskaia dissertatsia), defended in $1964 .{ }^{41}$ His ideas also developed in proximity to Vladimir Lefevr, who developed a theory of reflexive control in military strategy in his Conflicting Structures, first published in 1967..$^{42}$ According to Lefevr, one adversary can influence his opponent by imposing on the opponent one's own conceptual basis for decision-making. ${ }^{43}$ Lefevr's semiotic strategy of control would inspire Shchedrovitskii to develop psychological and system-analytical elaborations of the reflexive control of collective behaviour in non-military contexts.

If the 1970s were a period of intense development and internationalisation of systems analysis in the Soviet Union, for Shchedrovitskii this was a difficult time as he became ostracised for his political activism. In 1968 Shchedrovitskii signed a letter of support to the dissidents Aleksander Ginzburg and Iurii Galanskov and, as a consequence, was expelled from both the Party and VNIITE in March 1969. The publication of his work, a couple of monographs on the methodology of design, was disrupted. Nevertheless, thanks to the help of his friends, Shchedrovitskii found shelter at the experimental workshop of the All-Union of Artists, which enabled him to develop further his work on pedagogy and provided him with a modest income. These repressive measures did not discourage Shchedrovitskii from continuing his intellectual activities, quite the opposite, he remained actively involved in the development of the methodological circle ${ }^{44} \mathrm{He}$ managed to get employment in applied areas, such as sports research institutes. Whereas it seemed impossible for him to get affiliation with the prestigious and strategic institutes, such as the Institute of Systems Research (VNIISI, est. 1976) and the Institute of Control Sciences, where much of the innovative research into systems approach and forecasting was concentrated, Shchedrovitskii kept in touch 
with these milieus as he gave talks and participated in their seminars. ${ }^{45}$ His seminar and informal club were regarded with suspicion by the authorities, but his scientific approach was not. ${ }^{46}$ Indeed, subsequent developments testify to the substantial interest of highly positioned Soviet managers in Shchedrovitskii's work.

As he became an outcast of the Soviet academic mainstream, Shchedrovitskii responded by turning to entrepreneurship. In the late 1970s he embarked on the increasingly popular form of management training through business or simulation games, which he used as a vehicle to develop his theory of reflexive thinking-activity, combining Lefevr's notion of reflexive control, teleological behaviour and complexity, an important aspect of the systems approach. Whereas simulation games were developed at several new and influential institutes, such as VNIISI and the Academy of National Economy in Moscow, ${ }^{47}$ Shchedrovitskii's innovation was that he transferred this method to managerial practice, first and foremost to regional and urban planning.

\section{Reflexivity and the Soviet Future}

It is important to stress that Shchedrovitskii was not interested in producing end images of the future. Indeed, although he used many complex and sometimes bizarre schemes, his emphasis was on processes. Shchedrovitskii defines his methodology as an intense, reflexive formulation and coordination of group goals through the means of a highly formalised scientific method. Methodology, according to Shchedrovitskii, is first and foremost performative :

The essence of methodological work is not so much understanding, but the creation of methods and projects; it does not simply reflect, but rather builds, creates anew through constructing and projecting. ${ }^{48}$

He then continues :

[...] the principal products of methodological work, such as constructions, projects, norms, methodical prescriptions and so on, cannot be tested and are never tested as truthful. Only their do-ability can be tested. [...] When we project a city, it is meaningless to ask if our project is truthful, for this project corresponds not to a city that was, but to a city that will be ; the project does not reflect a city, but the city will realise the project. ${ }^{49}$

In these statements, as elsewhere, Shchedrovitskii posits his methodology as a value-neutral tool, a non-political technology: methodology is neither truthful nor false, it either works or does not. The question to what end methodology is working is the responsibility of managers, not methodologists. The role of a methodologist, according to Shchedrovitskii, is to create conditions enabling managers to learn projecting for the future through collective efforts of thinking-activity, where reflexivity plays an important role.

The original meaning of the word "reflexivity" entails looking back and not forward ; reflexivity describes "a mental action, process, etc. turned or directed back upon the mind itself ; involving intelligent self-awareness or self-examination"..$^{50}$ Yet we should remember that according to the cybernetic model, knowledge of the past (expressed in statistical trends or an initial state) is an absolutely necessary condition of prediction. This link is captured in Shchedrovitskii's notion of "forward reflexivity" or as it is sometimes translated into English, reflexiveness. ${ }^{51}$ To define his notion, Shchedrovitskii skilfully blended several legitimate theoretical traditions, drawing both on Hegelian and Marxist philosophies which underscore the role of conscious goal-setting for 
development. However, Shchedrovitskii drew conceptually on cognitive and system-cybernetic sciences, particularly their applications in Operations Research and defence, ${ }^{52}$ to devise his own specific notion of reflexivity as a new cognitive mechanism, which not so much "reflects back", but instead, "projects forward".

Shchedrovitskii's work was part of a wide movement in 1960s psychology and social science toward reflexivity. ${ }^{53}$ Furthermore, Shchedrovitskii's methodology is reminiscent of both French la prospective (indeed, he uses the term prospective, in Russian, prospektivnaia refleksiia) and of American business and policy simulation games. If la prospective was designed to facilitate strategic planning in large, bureaucratic organisations, such as state administration in France, American business games were developed to assist in solving concrete problems in firms. ${ }^{54}$ Both sought to establish informal relations across administrative divides, mobilising informality to generate new, alternative understandings of the future..$^{55}$ These methods, as noted by historian of science and technology Jennifer Light, were highly significant in state and urban planning in the US, yet we still lack knowledge of the uses of these methods in the Soviet Union..$^{56}$

In all, game simulation was a technique that bridged informal and formal organising. I suggest that the power of Shchedrovitskii's management training was not so much in the specific content of his theory of reflexive thinking-activity, but rather in its use, enabling Soviet managers to legitimately engage in informal negotiations about the future. If scientific forecasting, cybernetic systems and other predictive approaches aimed first and foremost at generating a formalised study of future developments and feeding this information to managers, Shchedrovitskii took a completely different route, arguing that his methods did not aim to offer certainty about the future, because "no one can tell beforehand what system-structural understandings are necessary" for resolving a managerial problem..$^{57}$ By this Shchedrovitskii meant that useful knowledge about the future could not be produced outside management activity. Instead, relevant knowledge, solutions and certainty can only emerge as a side-effect of group activity-thinking. Therefore these workshops facilitated the establishment of informal ties and the development of personal networks with the aim of pursuing practical projects in the future at the same time making the participants alert to governance as an intellectual, future-oriented activity.

Let us look more closely at activity games, a curious component of Russian management thinking that achieved surprising popularity in the 1980s. The origins of activity games can be traced to the post-NEP period, 1932, when Maria Birshtein (1902-1992) applied the method of war gaming to the management of a factory with the aim of increasing production. First affiliated with the Bureau of Scientific Organisation of Labour (NOT), Birshtein was later based at the Leningrad Institute of Engineering and Economics, where she developed a simulation game for a textile factory, running for 48 hours. This game enabled managers, engineers and administrators to establish ways of communicating across administrative divides that they later transferred to the actual working environment. Although proven successful, this method was short-lived : alongside all scientific approaches to management and economics, activity games were banned by Stalin in 1938. Birshtein survived Leningrad's blockade and resumed working during the post-Stalinist period. Her first complete work was published in 1989 and circulated in 30,000 copies..$^{58}$ 
30 It seems therefore that Shchedrovitskii creatively transferred Vygotsky's ideas on reflexivity, enriching them with Lefevr's notion of semiotic control, to the technique of simulation games, which he re-branded as activity-thinking (in Russian, mysledeiatel'nost). ${ }^{59}$ For us it is important that in doing this Shchedrovitskii relied on the notion of teleological behaviour, discussed earlier, according to which human behaviour is a goal-directed system where thinking is mobilized to both set the goals and regulate the behaviour through feedback. ${ }^{60}$ Following Vygotsky, and in contrast to structuralists, Shchedrovitskii contended that "the world is not structured through language [...] it is, in contrast, structured through activity (deiatel'nost')". ${ }^{61}$ An interesting point here is that if cybernetically-inspired organisation theory developed a notion of disembodied rationality, expressed in both computer technology and American game theory, Shchedrovitskii adopted a different approach, one closer to the cybernetic notion of autopoiesis, a circular process where "a living system's organisation causes certain products to be produced, ... [and] these products in turn produce the organisational characteristics of that living system". ${ }^{62}$ For Shchedrovitskii, collective reason was precisely such a case of societal autopoiesis, fundamentally embodied, social and enfolding through collective action. ${ }^{63}$

If prediction was about control, so was reflexivity: it was governmental applications that interested Shchedrovitskii. According to him, the governing system had to know the governed system. This was achieved by developing an understanding of the processes in the governed system, their causal relations, and having meta-knowledge of the processes of governance. This knowledge then was to be used to control, to overpower the governed system. Yet this overpowering was not to be imposed from outside, but rather internalised with the help of social mechanisms. According to his biographers, Shchedrovitskii did not believe in the production of policy-useful knowledge in the isolated environment of a scholar's office. The future was to be discovered jointly by the group of stakeholders, and the role of the scholar, or methodologist, was to guide this discovery with the help of techniques specially developed for the training sessions.

One of the earliest games concerning the supply of consumer goods to the Urals region was organised in August 1979. The design of this exercise took 25 days and involved co-production of both the method of self-organisation and goals that this self-organisation would strive to achieve. During this game (which lasted "only" nine days) in the village of Novaia Utka in Sverdlovsk region, the ineffective supply of consumer goods to the region was not solved as such, but was replaced with a different goal, to create a new "programme of complex research and projects" that would serve as a platform for solving this problem of the supply of consumer goods in the future. ${ }^{64}$ A participant in one of these first games wrote retrospectively just how innovative, for both local administrators and intellectuals, was the idea of goal-setting and an open future that was co-produced during the game. Habituated to repetitive re-affirmation of faithful implementation of the Party's plan, Soviet managers struggled to shape their own understanding, goals and projects. The whole process was mystifying for them : "Most different gossip was spreading and we whispered that this was Voland with his entourage". Georgii Shchedrovitskii, the witness wrote, "trained his team until exhaustion" meanwhile the locals did not interest him as such, except as a platform for developing his method. "We were", the witness wrote, "graduates from Ural universities, who did not possess either new ideas or high academic degrees, we had 
not been abroad, did not speak foreign languages and did not have experience of exploration, research, and analysis. [...] In all people enjoyed his [Shchedrovitskii's] internal dialogue". ${ }^{65}$ Here this participant described the seminar as an enjoyable show, but it is also clear from this account just how new the idea that management was an intellectual activity was for Soviet administrators. Shchedrovitskii himself regarded this game as particularly successful, writing that a whole range of goal-management tools were developed at Novaia Utka, and on the basis of this game he prepared 29 further games conducted in 1979-1981. The areas of application included the planning of nuclear power plants, cities, geological research, and higher education. ${ }^{66}$

Acitivity-games, wrote Shchedrovitskii were "a new, complex and systemic organizational form for team thinking activity", where the information was actually co-produced inside the meeting, the outcome being a new, better understanding of the situation. ${ }^{67}$ This was clearly a very performative understanding of knowledge :

[...] methodology was not simply a theory of the means and methods we employ in our thinking and activity, but was also a form of organization and thus a "framework" for all of people's vital activity, including thinking activity. This kind of methodology could not be transmitted, like knowledge or a set of instruments, from one person to another, but rather could only evolve, grow out of a context, as it were, through people's being brought into a sphere of methodological thinking activity that was new for them, but in which they were given the opportunity to participate in a complete and integral vital activity. ${ }^{68}$

It is quite striking that a previously marginalised scholar could now be involved in such a sensitive area of Soviet industry as nuclear energy. For example, Shchedrovitskii was approached by the Institute for Staff Training of the All-Union Ministry of Energy in Moscow to design an activity game for top managers at one of the most important Soviet nuclear plants, Beloiarsk, running from December 1980 to July $1981 .{ }^{69}$ Beloiarsk was the first Soviet nuclear plant using a particularly innovative fast breeder reactor BN-600, which in theory could recycle spent nuclear fuel, but which also produced plutonium close to weapons-grade. ${ }^{70}$ The construction of this unique power plant was going slowly. Thus in March and April Shchedrovitskii went to Zarechnyi to conduct an activity game on "Providing for the normal functioning and development of technologies and development of the Nuclear Power Plant". A striking feature of these activity games is that they were not so much about anticipating the unexpected, like the exercises of la prospective. Instead, Soviet activity games aimed to facilitate the recreation of conditions of "the expected" or "normal". ${ }^{71}$ The goal was to remove all the unexpected issues, a pervasive part of Soviet managerial reality, and co-produce certainty and mutual predictability among the management and engineers of the nuclear plant, hoping that this certainty would be transplanted into the actual running of the plant.

It is important here to pause and note that Shchedrovitskii understood predictability in a particular way. Shchedrovitskii was careful to distance himself as far as possible from forecasters: he hardly mentioned at all the central promoter of Soviet scientific forecasting, Igor' Bestuzhev-Lada, in his memoirs. This is because Shchedrovitskii understood prediction as a mere foretelling of the future; an end product that was decoupled from the context in which it was produced. Instead of prediction, Shchedrovitskii preferred traditional categories of management-speak, such as planning, programming and projecting. ${ }^{72}$ This choice of vocabulary, I suggest, was in fact a smart way to frame his method as a non-revolutionary, conservative tool that 
resembled Party planning discourses. Indeed, if Soviet scientific forecasters pushed for institutional reform, the Moscow methodologists never tried to change the existing institutional governmental framework. Instead they tapped directly into the source of real power: informal relations and networks, gearing their methodology to enable processes "here and now": situational analysis, goal-setting and situational problematisation. ${ }^{73}$

How, then, can a method that emphasises "here and now" produce a future? The answer is that the games enable the participants to "project and programme their future thinking-activity" and re-create this activity in any organisational context. ${ }^{74}$ According to Shchedrovitskii, "the central law and principle" of an activity-game is "organised chaos", an independently active (samodeiatel'naia), self-organising and self-developing system. ${ }^{75}$ And, as I mentioned earlier, Shchedrovitskii's "thinking-activity" underscored the collective and performative character of thinking, it is never a disconnected, solitary exercise. In contrast, for him thinking-activity could only be pursued as part of a team where a joint world (mir), amenable to control, would be constructed. Postulating that this world would include both governors and the governed and integrate their intersubjective understanding, Shchedrovitskii's approach resembled Erwin Goffman, who defined games as world-building activities and thus thinking-activity is a way to perpetuate an informal collective into the future. ${ }^{76}$ In this way, Shchedrovitskii's methodology mobilised a particular notion of governance, based on embodied, social and reflexive reason : an approach which was totally the opposite of RAND's game theory, such as the Prisoner's dilemma.

The activity-game approach was not only post-positivist, but also performative. Shchedrovitskii himself called his approach "constructionist-projecting" therefore abolishing the positivist division between object and subject, which held that the social, natural and technical spheres were separate. In contrast, Shchedrovitskii argued that when a manager deals with objects or technical systems, he or she inevitably confronts cognitive schemes, intentions and behaviour patterns of humans associated with these objects. His colleague, Boris Iudin, describes Shchedrovitskii's approach as an attempt to shift the focus of scholarship from the definition and control of individual objects to a complex of intellectual technologies which form the basis for the definition of and action upon the objects in question. Here a successful reflection was not the one generating new images, stories or precise data about the future, but a reflexive activity able to give continuous birth to new projects and action. As Shchedrovitskii remained a committed follower of Marxism, he borrowed from Marx the idea that scientific knowledge should be action-oriented and equipped it with the new vocabulary of systems theory, the cybernetic idea of feedback-based control and psychological techniques. ${ }^{77}$ In this way, the activity-game approach constituted a version of a highly sophisticated behaviorist governmentality, one that does not seek to engage with definitions of the subject, but rather is concerned with actions.

And yet it should not be forgotten that Shchedrovitskii sought to transform the rigid practice of Soviet planning by going beyond the mechanical implementation of the official plan targets. He argued that activity-thinking was a sociotechnics (sotsiotekhnika) that aimed to destabilise bureaucratic patterns of organisation, behaviour and thinking. ${ }^{78} \mathrm{~A}$ note is due here that Shchedrovitskii derived the term sociotechnics from the English term "systems engineering", applying the systems engineering approach to any organisational situation..$^{79}$ The idea was that sociotechnics 
dealt with hybrid objects or, as Shchedrovitskii called them, "centaurus objects", where human activities and objects were intertwined at the same epistemological level. ${ }^{80}$

The purpose of the games was to develop problems and not to find solutions to specific tasks; however, this was not revealed to game participants, who strove to resolve issues.$^{81}$ For example, Shchedrovitskii described an activity-game dedicated to the development of societal systems, which involved 160-190 participants in Krasnoiarsk in 1986 as follows :

So we, the gaming team, sought to "break out" from the present space of the activity into the space of history. I had really amused myself with my fellow-gamers there, took a chance to enjoy myself. Why so? The [theme of the] game was so [great] that everyone was saying, I, I, I will come! And they came. [...] I was saying, guys, excellent, since you are here, so get out! And they looked at me and said, we cannot see anything, it is dark and scary. I waited for a while and then suddenly pulled the carpet from underneath their feet, and they all went flying in the space of history, and it was very interesting to see how they jerked their little arms and legs". 82

To be sure, this quote is drawn from Shchedrovitskii's retrospective narrative and tells us more about his own approach to his seminars rather than what actually happened there. It is clear, however, that for Shchedrovitskii the goal of his methodology was disrupting existing templates of speaking about the past and future. This quote also reveals that he did not hide his own pleasure at watching people losing the safety of conventional meaning-making. An account of another activity-game, conducted with the municipality of Riga in Soviet Latvia (1986), noted that the chairman of the Riga city council realised that it was futile to try to solve managerial problems without a longer term, strategic understanding of the future of the city. ${ }^{83}$ Using the long term to frame current problems in the context of either the past or the future, Shchedrovitskii aimed to estrange Soviet managers from their minute, day-to-day problem solving and by virtue of reflecting back on themselves - in their organisational roles that formed part of a larger governmental project - to project themselves into the far future. ${ }^{84}$

\section{Post-Soviet Legacy}

41 The case of Shchedrovitskii is central for understanding the post-Soviet transformation. Emphasising reflexivity, taking into account interaction between human and material systems as they were enmeshed together and projected into the future, Shchedrovitskii's methodology foregrounds a shift in Soviet management, where a centrally commanded system was replaced by a market economy and Marxist-Leninist ideology was replaced by complex semiotic technologies of manipulating public opinion and consumer behaviour. This is not to say that Shchedrovitskii exerted direct influence on post-Soviet leaders, but rather to suggest that Shchedrovitskii's methodology played a highly important role in enabling much of the top Soviet management to cope with the transition from a centrally-commanded, politicised system to the market economy and complex world of new media technologies. Although Georgii Shchedrovitskii did not live to see the boom of the media and internet technologies of the 1990s, his theoretical vocabulary bridged the model of ideological indoctrination and complex, systems theory-based models of reflexive control of collective behaviour. 

extent by his son Petr, who pioneered much of the strategy training in the public sector of the Russian Federation, established a School of Cultural Policy and, in 2005, the Scientific Foundation of Georgii Shchedrovitskii in Moscow. Petr Shchedrovitskii himself became a highly influential management consultant and political technologist in Russia: he claims to have trained about 100,000 managers, ranging from cultural managers to diamond producers. Also, from the year 2000 he co-authored and widely disseminated the idea of the "Russian world" (Ruskii mir), or global and transnational communities of Russian speakers, who can be strategically mobilised to pursue Russia's national goals..$^{85}$ Furthermore, in recent years, the intellectual legacy of Georgii Shchedrovitskii has been institutionalised through the many volumes republishing his articles, lectures and activity-game training sessions. Histories of Russian managerial thought inevitably include Shchedrovitskii as an important phenomenon and attempts are made to introduce him in English and French, where highly positioned officials in Putin's regime pay homage to Shchedrovitskii's methodology. ${ }^{86}$

Shchedrovitskii's work is therefore deeply ambivalent. In the 1970s-1980s Shchedrovitskii's notion of thinking-activity constituted an important break in the governmental logic of progressive time and, in turn, the communist future as laid out in the Party's plans. In contrast to an input-output model of predictive expertise, where specialists feed data to policy makers to help them to make informed decisions, Shchedrovitskii's method is not linear : there is no clear division between language, thinking and behaviour, subject and object. Instead, Shchedrovitskii's method underscores the reflexive and performative character of thinking in a group : he argues that ideas cannot be separated from subjects and thinking is a form of activity. A study of this phenomenon thus cannot claim to merely deconstruct this mentality of governance by revealing its hidden social or political rationales; this is simply because thinking-activity is an open (documented in publications) but opaque, indeed, anarchic method that both acknowledges and boasts its manipulative power, while rejecting the idea of any singularly defined "truths", be they efficiency, rationality or order. There is also an issue of source materials : only some moments of the thinking-activity games, usually the follow-up discussions, were recorded.

\section{Conclusion : Reflexive Authoritarian Future?}

This article argues for the importance of thinking-activity and organisational-activity games as a form of scientific governmentality of the future in the Soviet Union. Unlike scientific forecasting, which produced detailed images of the future in graphs and maps of statistical trends, thinking-activity was a performative intellectual technology, which sought to destabilise the Soviet present by overthrowing the administrative and conceptual frameworks that guided the managers who participated in Shchedrovitskii's games. The idea was to undermine the rigidly defined administrative bureaucratic roles, which were strongly linked with specific, short-term problems and enmeshed in "avral", or last-minute management. The breaking down of this framework, according to Shchedrovitskii, gave an opportunity to the managers to think about the long term and develop a more holistic, systemic view of their governmental task. Yet what did the long term future hold in Shchedrovitskii's seminars? 

seminars, aimed at fostering trust and informal relations, probably led to the building of new, horizontal ties, thus undermining the existing, centralised and bureaucratic hierarchies. The informality promoted by Shchedrovitskii was substantially different from the economy of favours or "blat". Shchedrovitskii's seminars, esoteric and conducted in remote places, clearly had an aura of access to exclusive, esoteric knowledge, or rather skills, as they broke away from the usual bureaucratic milieus with the aim of encouraging autonomous goal-setting. Here, management was dissociated from the mere implementation of Party plans and transformed into a collective, reflexive goal-setting activity. Shchedrovitskii also juxtaposed his method to scientific forecasting, saying that forecasting only provides knowledge about the "self-developing", "natural world", whereas reflexive thinking-activity, expressed in programming and projecting, was part of human teleological behaviour. ${ }^{87}$

Hence Shchedrovitskii was not fully consistent: although he defined organising as sociotechnics, blurring the boundaries between humans and natural objects, when it came to the institutional positioning of his methodology, he claimed that the method of scientific forecasting could only be applied to predict the "natural world", whereas thinking-activity applied to human behaviour. This conceptual inconsistency was probably rooted in his desire to stand apart from the Soviet forecasting community, as they were closely integrated in the administrative planning system. With his "methodology" Shchedrovitskii sought to empower Soviet managers and directors, enabling them better to control their workers, but these were soft, semiotic methods of control that had nothing to do with ideological indoctrination or repression. In the Soviet context, Shchedrovitskii thus introduced a new notion of the future as an enfolding reality that is brought into being through what he called "forward reflexiveness". ${ }^{88}$

However, unlike scientific forecasting, Shchedrovitskii's technique did not challenge the existing hierarchies and rules of Soviet bureaucracy. If scientific forecasters at the Gosplan Research Institute of Economics called for transparency and more open circulation of data, ${ }^{89}$ the sessions of organisational-activity games would foster the formation of informal, non-transparent networks never aimed at reforming the system itself. Unlike economic forecasters, dismissed as elitist technocrats, Shchedrovitskii's managers remained invisible socio-political technologists. Although some scholars interpreted Shchedrovitskii's seminars as examples of Soviet civil society, their effects were rather ambivalent. For sure, these seminars brought together new socio-political elites and encouraged their informal self-organisation. It is quite possible that informal ties, symbolically reinforced by Shchedrovitskii's scientific authority, were more important than the future visions themselves, forged in the discrete, laboratory-like locations of activity-games.

But an answer can also be found in the conserving effect of the activity games that sought to discover the conditions for the "normal" rather than to experiment with the conditions for radically new things. Even in the late 1980s Georgii Shchedrovitskii emphasised that his method is different from the alarmist and critical warnings of other scientists, who sought, in the words of Aaron Wildawsky, to "speak truth to power". Instead, thinking-activity is geared to providing "concrete solutions", the key emphasis being on coordination and self-regulation beyond formal bureaucratic structures. Thus in Shchedrovitskii's circles the power to shape the future became 
linked to the notion of an informal community, integrated through informational processes. After 1991, the reflexive methodology of Shchedrovitskii lost its alter ego, the centralised command economy, to become a tool in the hands of the new Russian political technologists, but the later political career of this reflexive technology of the future is a subject for a different study.

\section{NOTES}

1. I thank Irina Sandomirskaja, Francis Dodsworth, Nadège Ragaru, Jenny Andersson and Alena Ledeneva, and three anonymous reviewers for their helpful comments. The views and errors, naturally, are the author's only.

2. These are the studies on utopia, modernist projects in the arts, architecture and design, society and industry. See, for instance, Boris Groys, The Total Art of Stalinism : Avant-garde, Aesthetic Dictatorship and Beyond (Princeton : Princeton University Press, 1992) ; David Crowley, Jane Pavitt, eds, Cold War Modern 1945-1970 (London: V\&A, 2010) ; Richard Stites, Utopian Vision and Experimental Life in the Russian Revolution (Oxford : Oxford University Press, 1989); Edith Cloves, Russian Experimental Fiction: Resisting Ideology after Utopia (Princeton: Princeton University Press, 1993) ; Paul Josephson, "Projects of the Century" in "Soviet History : Large Scale Technologies from Stalin to Gorbachev," Technology and Culture, 36, 3 (1995) : 519-559.

3. Here I draw on the larger research agenda on global future studies advanced by Jenny Andersson. For a discussion, see Jenny Andersson Eglè Rindzevičiūtè, "Introduction : Toward a New History of the Future," in Jenny Andersson, Eglè Rindzevičiūtè, eds, The Struggle for the Long-Term in Transnational Science and Politics: Forging the Future (London \& New York, Routledge, 2015).

4. See Eglè Rindzevičiūtè, “Towards the Joint Future Beyond the Iron Curtain : East-West Politics of Global Modelling", in Andersson and Rindzevičiūtè, eds., The Struggle for the Long Term.

5. Alena Ledeneva, How Russia Really Works : The Informal Practices that Shaped Post-Soviet Politics and Business (Ithaca: Cornell University Press, 2006); Carole Sigman, "Les clubs politiques informels acteurs du basculement de la perestroïka," Revue française de science politique, 5, 58 (2008) : 617-642 ; Alena Ledeneva, Russia's Economy of Favours : Blat, Networking and Informal Exchange (Cambridge : Cambridge University Press, 1998).

6. Eglè Rindzevičiūtè, "A Struggle for Soviet Future: The Birth of Scientific Forecasting in the Soviet Union," Slavic Review (forthcoming, Spring 2016).

7. Georgii Shchedrovitskii, "Sistemnoe dvizhenie i perspektivy razvitiia sistemno-strukturnoi metodologii [The systems movement from the perspective of development of system-structural methodology]," in Georgii Shchedrovitskii, Izbrannye Trudy [Æuvres choisies] (M. : Shkola kul 'turnoi politiki, 1995), 57-87.

8. Existing studies on Soviet management distinguish a group of "Americanisers" who directly borrowed US ideas of leadership and human interaction. Focusing on the formalisation of governance through institutional design, new technologies of data processing and control, such as computers and computer networks, and planning techniques, these studies overlooked the important role of Shchedrovitskii in the development of Soviet governmentality. Richard 
Vidmer, "Management Science in the USSR : The Role of 'Americanizers'," International Studies Quarterly, 24, 3 (1980) : 392-414, 402.

9. For example, Shchedrovitskii is absent from a recent Russian history of management thought. N.V. Ovchinnikova, ed., Istoriia upravlencheskoi mysli [The history of governmental thought] (M. : RGGU, 2013). The only historical study on Shchedrovitskii is in French and discusses his thought and practice exclusively in relation to Marxist philosophy, social theory and social psychology, Svetlana Tabatchnikova, Le cercle de méthodologie de Moscou (1954-1988) : une pensée, une pratique (P. : EHESS, 2007).

10. Tatiana Osintseva, "Novaia utka," Prometa.ru. Accessed 10 April 2015.

11. See fondgp.ru.

12. I base this statement on a Google Scholar search. The catalogue of the National Library of Russia lists over 1,700 doctoral dissertations that quote Shchedrovitskii's work, dating from the 1990s.

13. See Viktor Khristenko, Aleksandr Reus, Aleksandr Zinchenko et al., Methodological School of Management (London : Bloomsbury, 2014).

14. For a comparative analysis of high modernism see James Scot, Seeing Like a State: How Certain Schemes to Improve Human Condition Have Failed (New Haven : Yale University Press, 1999).

15. For a well-structured overview of different methods of forecasting, see J. Scott Armstrong, Long-Range Forecasting: From Crystal Ball to Computer (New York \& Chichester : Wiley, 1985) ; for governmental uses of statistics, Alain Desrosières, The Politics of Large Numbers : A History of Statistical Reasoning (Cambridge : Harvard University Press, 1998). For an overview of the role of predictive technologies in high modernist state see Jenny Andersson, "Governing Futures : States and the Management of Expectations," in Patrick Le Gales, Desmond King, Rethinking the State (Oxford, forthcoming).

16. For technocracy see Frank Fischer, Technocracy and the Politics of Expertise (Newbury Park \& London: Sage, 1990); see also Peter Galison, Bruce William Hevly, eds., Big Science: The Growth of Large Scale Research (Stanford : Stanford University Press, 1992).

17. Some Russian commentators attribute to Shchedrovitskii, alongside with authors of Soviet science fiction, a new way of envisioning the social future that emerged in the 1960s. But others, like Kukulin, note that Shchedrovitskii's method had many non-democratic implications. See Il'ia Kukulin, "Alternative Social Blueprinting in Soviet Society of the 1960s and the 1970s, or Why Left-Wing Political Practices Have Not Caught on in Contemporary Russia," Russian Studies in History, 49, 4 (2011) :51-92.

18. Georgii Shchedrovitskii, Orgupravlencheskoe myshlenie: ideologiia, metodologiia, tekhnologiia [Organisational-governmental thinking: ideology, methodology, technology] (M. : Studia Artemeva Lebedeva, 2013), 154.

19. Jenny Andersson, "Midwives of the Future : Futurism, Futures Studies and the Shaping of the Global Imagination," in Andersson, Rindzevičiūtè, eds.,The Struggle for the Long Term.

20. Michel Foucault, Security, Territory, Population : Lectures at the Collège de France, 1977-1978 (Basingstoke : Palgrave Macmillan, 2009), 108-109.

21. Shchedrovitskii himself inscribes the history of his approach in the context of East-West transfer of management sciences, such as systems analysis and the operations research. To be sure, the historical context could go back to the interwar and even earlier period, where system thinking began to emerge in the fields of engineering and biology, both in Western Europe, the US but also, in the thought of Alexander Bogdanov. Schedrovitskii's thought also derived its inspiration from the interwar linguistics and pedagogy. Yet due to space limitation, in this article I focus my discussion on the postwar development of cybernetics and systems analysis, the fields that gave legitimacy to Shchedrovitskii's work during the Soviet period. 
22. Arturo Rosenblueth, Norbert Wiener, Julian Bigelow, "Behavior, Purpose and Teleology," Philosophy of Science, 10 (1943) :18-24.

23. For the development of cybernetics in the Soviet Union, see Slava Gerovitch, From Newspeak to Cyberspeak : A History of Soviet Cybernetics (Cambridge, MA : The MIT Press, 2002).

24. Frank Kaplan, The Wizzards of Armaggedon (Stanford: Stanford University Press, 1991) ; David Jardini, Out of the Blue Yonder: The RAND Corporation's Diversification into Social Welfare Research, 1946-1968 (Carnegie Mellon, an unpublished PhD dissertation, 1996). For a good overview of policy sciences see Philip Mirowski, Machine Dreams : Economics Becomes a Cyborg Science (Chicago : Chicago University Press, 2001).

25. Rindzevičiūtè, "A Struggle for the Soviet Future."

26. S.M. Amadae, Rationalizing Capitalist Democracy : Rational Choice Liberalism (Chicago : The University of Chicago Press, 2003) ; Paul Erickson et al, How Reason Almost Lost Its Mind : The Strange Career of Cold War Rationality (Chicago : The University of Chicago Press, 2013).

27. Rindzevičiūtè, "A Struggle for the Soviet Future," and Rindzevičiūtè, "Towards the Joint Future Beyond the Iron Curtain."

28. Paul Gregory, The Political Economy of Stalinism : Evidence from the Soviet Secret Archives (Cambridge : Cambridge University Press, 2004).

29. See Ledeneva and Stephen Fortescue, ed., Russian Politics from Lenin to Putin (Basingstoke : Palgrave Macmillan, 2010).

30. This led some scholars to propose that it was KGB and not scientific experts that played the central role of information processing in the Soviet governance. Scott Shane, Dismantling Utopia : How Information Ended the Soviet Union (Chicago : Ivan R. Dee, 1994). See also Michael Ellman and Vladimir Kantorovich, eds. The Destruction of the Soviet Economic System: An Insider's History (London and New York : Routledge, 1988).

31. Georgii Shchedrovitskii, Ia vsegda byl idealistom... [ I have always been an idealist ] (M., 2001), 62-67.

32. Shchedrovitskii, Ia vsegda, 74-75.

33. Georgii Shchedrovitskii, "Lektsiia $1: 18$ fevralia 1988 [ Lecture 1, 18 February 1988 ]," in Zapisi Rizhskogo metodologicheskogo seminara, vol. 1 [Notes from the Riga seminar on methodology] (Riga : BISI, 2010), 27-28.

34. Shchedrovitskii, "Lektsiia 1," 17, 52.

35. Shchedrovitskii often cited academic literature in English. He read the principal works in systems analysis by Quade, Optner, Ackoff, Bertalanffy, Anatolii Rapoport, and Herbert Simon, many of which were translated, but also available in the original language at Moscow libraries. Shchedrovitskii often refers to structuralists, such as Saussure and Parsons. It is somewhat odd, however, that he does not refer to any Western works on business games. See Georgii Shchedrovitskii, Izbrannye trudy.

36. Dmitry Azrikan, “VNIITE, Dinosaur of Totalitarianism or Plato's Academy of Design ?” Design Issues, 15, 3 (1999) : 45-77.

37. For an overview of Soviet forecasting, see Rindzevičiūtè, "A Struggle for the Soviet Future."

38. Vesa Oittinen, ed., Evald Ilyenkov's Philosophy Revisited (Helsinki : Kikimora, 2000).

39. This seminar was criticised by some influential hardliners, such as a philosopher, academician Todor Pavlov. Georgii Shchedrovitskii, "Problemy metodologii sistemnogo issledovaniia (1964) [The methodological problems of systems research]," in Shchedrovitskii, Izbrannye; also "K tvorcheskoi biografii G.P. Shchedrovitskogo (1929-1994) [ Toward an intellectual biography of G.P. Shchedrovitskii]," in Shchedrovitskii, Izbrannye (1995), xxiii-xxiv.

40. Georgii Shchedrovitskii, Problemy metodologii sistemnogo issledovaniia.

41. See the biography on www.fondgp.org.

42. Vladimir Lefevr, Konfliktuiushchie struktury [Conflicting structures] (M. : Vysh.shkola, 1967). 
43. Timothy L. Thomas, "Russia's Reflexive Control Theory and the Military", Journal of Slavic Military Studies, 17 (2004) :237-256.

44. Reportedly, all the signatories of this letter lost their professional jobs. Shchedrovitskii would be able to publish again in a few years after the repression. Thus, in addition to many articles, he co-authored a monograph on automated systems in design, together with Oleg Genisaretskii and Anatolii Rapaport, among others, published in 1975. Anatolii Piskoppel', "K tvorcheskoi.." xxxii-xxxiii.

45. Piskoppel', "K tvorcheskoi...", xxxii-xxxiii.

46. Biographers note that several colleagues of Shchedrovitskii left his circle in the mid-1970s, because they thought that their participation in this informal collective could obstruct their careers. Piskoppel', "K tvorcheskoi...”, xxxiii.

47. Nickolai Lapin, Boris Sazonov, "The Activity-Systems Approach to Development of the Human Factor in Innovation," in Stuart A. Umpleby, Vadim N.Sadovsky, eds., A Science of Goal Formulation : American and Soviet Discussions of Cybernetics and Systems Theory (New York : Hemisphere, 1991), 195-206.

48. Georgii Shchedrovitskii, "Printsipy i obshchaia schema metodologicheskoi organizatsii sistemno-strukturnykh issledovanii i razrabotok (1981) [Principles and the general scheme of methodological organisation of system-structural research and applications]," Izbrannye trudy, 95.

49. Shchedrovitskii, "Printsipy".

50. See the entry in the Oxford English Dictionary, www.oed.com. Accessed on 10 April 2015.

51. Georgii Shchedrovitskii, "Mental Activity and Pure Thought,"in Khristenko, Reus, Zinchenko et al., Methodological School of Management, 38.

52. Namely, the work of Lefevr, see Georgii Shchedrovitskii, "Refleksiia [Reflexivity]" (1974), in Izbrannye trudy, 485-495.

53. For a discussion of different modes and historical development of reflexivity, see Margaret Archer, The Reflexive Imperative in Late Modernity (Cambridge : Cambridge University, 2012) ; Roger Smith, "Does Reflexivity Separate the Human Sciences from the Natural Sciences?" History of the Human Sciences, 18, 4 (2005) :1-25.

54. George Dantzig and Jay Forrester were among the first to develop computer applications for group decisions. For RAND and planning see Jennifer S. Light, From Warfare to Welfare : Defense Intellectuals and Urban Problems in Cold War America (Baltimore: John Hopkins University Press, 2003) ; Jennifer Light, "Taking Games Seriously", Technology and Culture, 49, 2 (2008) : 347-375. For an overview of business games, see Joseph Wolfe, "A History of Business Teaching Games in English-Speaking and Post-Socialist Countries: The Origination and Diffusion of a Management Education and Development Technology," Simulation and Gaming 24, 4 (1993): 445-463 ; D.J. Power, A Brief History of Decision Support Systems, DSSResources.com, version 4.0 (10 March 2007).

55. See, for instance, Michel Godet, "From Forecasting to la prospective : A New Way of Looking at Futures," Journal of Forecasting, 1 (1982) : 293-301; Tuomo Kuosa, The Evolution of Strategic Foresight: Navigating Public Policy Making (Aldershot: Ashgate, 2012). On la prospective as a form of social engineering, see Jenny Andersson, "RAND Goes to France : comprendre les origines de la prospective française", in preparation.

56. These gaming techniques were sometimes mediated by computer technology but not always (and never in Shchedrovitskii's games in the Soviet Union). Business-games were also developed in many Soviet research institutes, which cooperated with both the West and Eastern bloc. See Audra Wolfe, Competing with the Soviets: Science, Technology, and the State in Cold War America (Baltimore : Johns Hopkins University Press, 2013), 455-456.

57. Georgii Shchedrovitskii, "Printsipy i obshchaia schema metodologicheskoi organizatsii sistemno-strukturnykh issledovanii i razrabotok (1981)," 112. 
58. John H. Gagnon, "Mary M. Birshtein : The Mother of Soviet Simulation Gaming," Simulation Gaming 18,3 (1987) : 3-12 ; M. Belchikov and M.M. Birshtein, Delovye igry [Business games] (Riga : AVOTS, 1989).

59. Georgii Shchedrovitskii, “Organizatsionno-deiatel'nostnaia igra kak novaia forma organizatsii i metod razvitiia kollektivnoi mysledeiatel'nosti (1983),[Organisational activity game as a new form of organisation and a method of development of collective thinking-activity]" in Shchedrovitskii, Izbrannye, 115-142.

60. Gregory Bedny, Mark Seglin, David Meister, "Activity Theory: History, Research and Application," Theoretical Issues in Ergonomics Science 1, 2 (2000) : 168-206.

61. Georgii Shchedrovitskii, “Lektsiia $2: 19$ fevralia 1988," Zapisi Rizhskogo, 65.

62. Katherine Hayles, How We Became Posthuman : Virtual Bodies in Cybernetics, Literature, and Informatics (Chicago \& London : The University of Chicago Press, 1999), 136.

63. For an influential critique of disembodied reason see Hayles; for the construction of political individualism in game theory see Amadae.

64. Georgii Shchedrovitskii, “Organizatsionno-deiatel'nostnaia igra kak novaia forma organizatsii i metod razvitiia kollektivnoi mysledeiatelnosti (1983)," 121, 124-5.

65. Osintseva, "Novaia Utka."

66. Shchedrovitskii, "Organizatsionno-deiatel'nostnaia," 127-128.

67. Georgii Shchedrovitskii, S.I. Kotel'nikov, “Organizatsionno-deiatel'nostnaia igra kak novaia forma organizatsii i metod razvitiia kollektivnoi mysledeiatel'nosti”, in Izbrannye, 113-142.

68. Shchedrovitskii, Kotel'nikov, “Organizatsionnaia," 118.

69. Petr Shchedrovitskii, "Predislovie [Foreword]," in Georgii Shchedrovitskii, Orgupravlencheskoe myshlenie : ideologiia, metodologiia, tekhnologiia (Moscow : Izdatel'stvo Studii Artemiia Lebedeva, 2014 http://www.artlebedev.ru/everything/izdal/orgupravlencheskoe -myshlenie/).

70. I thank Tatiana Kasperski for the information on Beloiarsk nuclear power plant.

71. Shchedrovitskii, "Predislovie."

72. See the story narrated by Georgii Shchedrovitskii, "Perspektivy i programmy razvitiia SMD-metodologii [Perspectives and programmes of the development of methodology of systemic thinking-activity]," www.bdn-steiner.ru. Accessed on 10 April 2015.

73. Shchedrovitskii, “Organizatsionno-deiatel'nostnaia igra kak novaia forma organizatsii," 138.

74. Ibid., 140.

75. Ibid., fondgp.ru.

76. Erwin Goffman, Encounters (New York, 1961), cf Jennifer Light, “Taking”, 372.

77. Boris Iudin, "Ot gumanitarnogo znaniia k gumanitarnym tekhnologiiam [From humanities knowledge to humanities technologies]," Gumanitarnye nauki : teoriia i metodologiia, 4 (2005) : 104-107.

78. Shchedrovitskii, “Organizatsionno-deiatel'nostnaia igra kak novaia forma organizatsii," 141.

79. Shchedrovitskii refers to the Russian translation (1962) of the work of US scholars, Harry Good, Robert Machol, Systems Engineering: An Introduction to the Design of Large-Scale Systems (New York : Mc Graw Hill, 1957).

80. Georgii Shchedrovitskii, "Budushchee est' rabota myshleniia i deistviia [The future is a work of thinking and activity]," Voprosy metodologii, 3-4 (1994). Available at fondgp.ru, accessed on 15 April 2015.

81. Shchedrovitskii, “Organizatsionno-deiatel'nostnaia igra kak novaia forma organizatsii myslediatel'nosti".

82. Shchedrovitskii, "Lektsiia 2," 71.

83. Shchedrovitskii, "Lektsiia 2."

84. Such an emancipation was questioned by the representatives of the ideological control at these workshops ; for instance, in the case of a different game on free elections, a high official in 
the Riga city government warned the participants to "behave themselves," something which a game technologist Sergei Popov refused to do. Georgii Shchedrovitskii, Organizatsiia, rukovodstvo, upravlenie II [Organisation, leadership, governance] (M. : Put', 2003), 36-37.

85. For more on the Russian world, see Michael Gorham, "Virtual Rusophonia : Language Policy as 'Soft Power' in the New Media Age," Digital Icons, 5 (2011) : 23-48; Andis Kudors, "Russian World' : Russia's Soft Power Approach to Compatriots Policy," Russian Analytical Digest, 81 (16 June 2010) : 2-4.

86. Violetta Volkova, Iz istorii teorii sistem i sistemnogo analiza [From the history of the theory of systems and systems analysis] (SPb.: SPbGPU, 2004); also Tabatchnikova, Le cercle; V.B. Kristenko, A.G. Reus, A.P. Zinchenko, eds. Methodological School of Management (London : Bloomsbury, 2014).

87. Georgii Shchedrovitskii, "Budushchee est' rabota myshleniia i deistviia."

88. Shchedrovitsky, Moscow Methodological, 38.

89. For more on scientific forecasting and glasnost' see Rindzevičiūtè, "A Struggle for Soviet Future."

\section{ABSTRACTS}

This article examines the ways in which the future as a dimension of goal-oriented behaviour was used to organise and legitimise informal practices of management and planning in the Soviet Union. This study introduces the hitherto unexplored history of reflexive management under an authoritarian regime, focusing on the work of Russian philosopher and management guru Georgii Shchedrovitskii. Drawing on the cybernetic notion of teleology, which posited reflexive goal-setting as a key condition for control, Shchedrovitskii taught Soviet managers to formulate their own goals, thus contributing to the erosion of the Communist Party's monopoly of goalsetting. Furthermore, through the means of organisational-business games this new teleology not only transformed bureaucratic administrations into informal collectives, but also provided informality with an unprecedented legitimacy, emancipatory in the Soviet context, but highly ambiguous in the post-Soviet era.

L'article examine comment le futur - ici envisagé en tant que technique spécifique d'orientation vers l'avant - a été utilisé en Union soviétique pour organiser et légitimer des pratiques informelles de gestion et de planification. Cette étude aborde l'histoire, encore inexplorée, du management réflexif dans un régime autoritaire en se centrant sur l'œuvre de Georgij Ščedrovickij, philosophe russe et gourou en management. Empruntant à la notion cybernétique de téléologie (qui faisait de la réflexivité dans la définition des objectifs une condition clé du contrôle), Georgij Ščedrovickij a enseigné aux gestionnaires soviétiques comment formuler des buts propres. Ce faisant, il a contribué à l'érosion du monopole du parti communiste en matière d'objectifs. En outre, à travers le maniement de jeux de gestion et d'organisation, cette nouvelle téléologie n'a pas seulement transformé les administrations bureaucratiques en des collectifs informels, elle a aussi conféré une légitimité inédite à l'informalité - une légitimité émancipatrice dans le contexte soviétique, mais hautement ambiguë à l'ère postsoviétique. 
AUTHOR

EGLE RINDZEVIČIŪTĖ

Centre d'études européennes, Sciences Po, Paris, egle.rindzeviciute@sciencespo.fr 